\title{
Make It Memorable: Tourism Experience, Fun, Recommendation and Revisit Intentions of Chinese Outbound Tourists
}

\author{
Xin Chen ${ }^{1}$, Zhen-feng Cheng ${ }^{2}$ and Gyu-Bae Kim ${ }^{3, *}$ \\ 1 College of Landscape Architecture and Tourism, Hebei Agricultural University, Baoding 071000, China; \\ ylchx@hebau.edu.cn \\ 2 Department of Economics and Trade, Guangzhou College of Technology and Business, Guangzhou 510850, \\ China; czfmanager@sina.com \\ 3 Department of Business Administration, Daejeon University, Daejeon 34520, Korea \\ * Correspondence: gbkim@dju.ac.kr; Tel.: +82-42-280-2194
}

Received: 16 February 2020; Accepted: 2 March 2020; Published: 3 March 2020

check for updates

\begin{abstract}
Due to the fact that Chinese tourists are becoming the main players in the international tourism market, with large growth potential, this research empirically identifies the psychological factors that affect Chinese outbound tourists' memorable tourism experiences (MTEs), and investigates the relationships among MTEs, the "fun" emotion, and their recommendation and revisit intentions based on the stimulus-organism-response (S-O-R) model. In addition, the moderating role of perceived risk between the causal relationships among the "fun" emotion and recommendation and revisit intentions is identified. A total of 560 survey participants who had experienced overseas tourism in the last two years were selected as the target population, and the data from 413 valid surveys were empirically analyzed via structural equation modeling (SEM). Chinese outbound tourists' MTEs, such as hedonism, novelty, meaningfulness, and social interaction, are found to positively influence their experience of the "fun" emotion, such as emotional spark and flow. Additionally, it is found that when Chinese outbound tourists have achieved a high level of the "fun" emotion, their intentions to recommend and revisit their destination will be stronger. In addition, perceived risk is found to have a negative moderating role in the causal relationships among emotional spark and recommendation and revisit intentions, and also has negative moderating effects on the causal relationship between flow and recommendation intentions. This study provides important practical insights for how international tourist destination marketers and managers provide Chinese tourists with MTEs, and how to elicit the "fun" emotion and loyalty behaviors from Chinese tourists via the investigation of the mechanism of MTEs, fun, and recommendation and revisit intentions. It is also found that it is beneficial for international tourist destination managers to lower the level of tourists' perceived risk to improve tourists' recommendation and revisit intentions. These findings can aid in the development of more effective strategies to increase the market share and the international competitiveness of destinations.
\end{abstract}

Keywords: MTEs; fun; recommendation intention; revisit intention; perceived risk; Chinese outbound tourists

\section{Introduction}

With continued technological innovation and economic development, global society has been integrated politically, economically, and culturally. Along with this trend, international travel has become an imperative driving force of tourism development [1]. According to the UNWTO Tourism Towards 2030 research project, the number of international tourists will grow by $3.3 \%$ each year 
beginning from 2010, and this growth will culminate in 1.8 billion international tourists in 2030 [2]. Relevant research has found that international tourism is conducive to the increase of foreign exchange earnings, job creation, and tax revenues, as well as to the improvement of core competitiveness, and plays an important role in global economic recovery $[1,3,4]$. Therefore, determining how to enhance the competitiveness of the domestic tourism market and attract more international tourists has become a major challenge faced by academics and industry practitioners.

China has been the greatest source of international tourists worldwide since 2012 [5], and has produced more than 100 million outbound tourists since 2014; this figure is projected to rise [6]. Therefore, the investigation of Chinese tourists' preferences and behavioral intentions is critical for international tourist destination marketers to sustain the fast-growing tourism economy [7-10]. However, a critical question must first be asked: When Chinese tourists become the main players in the international tourism market, will destination marketing strategies based on fundamental utilitarian needs continue to be effective?

Chinese tourists are predominantly attracted by shopping [11]. However, there is growing concern that simply relying on shopping to attract these visitors may not be sufficient to create experiential value and build ongoing relationships [12]. According to Myagmar and Choi [13], we must think beyond basic utilitarian needs to better understand today's consumers in the experience economy. It has been found that the key to gaining advantages is the creation of high-quality hedonic experiences [14], as creating meaningful travel experiences may be a key factor in tourism marketing and customer retention; increasingly, more tourists are consciously seeking memorable and unique tourism experiences [15-17]. This means that marketers must pay more attention to creating memorable tourism experiences (MTEs) and improving experience quality at every interaction point.

It has been indicated that consumer satisfaction is an important antecedent of loyalty [18-21]. However, with the increase of the importance of consumer experience, researchers and practitioners have turned their attention to consumer experience and emotion as a new strategy for creating consumer loyalty [22,23]. Existing research has indicated that emotions are an important outcome of tourists' consumption experience, and that tourists' positive emotions are related to their satisfaction and loyalty $[24,25]$. Understanding how to elicit the "fun" emotion from tourists is very useful for designing MTEs that meet specific travel needs [26]. Therefore, MTEs can be considered to be important predictors of positive emotions, such as fun, and tourist behavioral intentions. In addition, in view of the important influence of Chinese tourists on the international tourism market, global tourist destination marketers must more clearly determine how to provide MTEs for Chinese tourists, and elicit positive behavioral outcomes from them, such as recommendation and revisit intentions [27]. However, while researchers have devoted significant efforts to the exploration of Chinese outbound tourists' motivations, perceived destination images, travel restrictions, and behavioral issues $[8,10,28]$, the specific experiences that affect the positive emotions and behavioral outcomes of tourists require further identification.

Additionally, although some studies have proven that positive emotions and satisfaction are necessary precursors of loyalty behavior [14,18,22,29,30]), Prayag et al. [31] pointed out that there are interference factors between positive emotions and loyalty behavior. However, there is scarce research that has investigated the boundary conditions between tourists' positive emotions and their loyalty behaviors, particularly, in the context of China's outbound tourism market.

To fill the gaps in the existing research, this study not only explores the mechanism of the effect of Chinese outbound tourists' "fun" emotion on positive behavioral intentions, but also further explains the boundary conditions of their positive emotions on their recommendation and revisit intentions. Thus, this research aims to examine how Chinese outbound tourists' positive emotions and behavioral intentions can be elicited by modeling the relationships among MTEs, the "fun" emotion, recommendation and revisit intentions, and perceived risk based on the stimulus-organism-response (S-O-R) model [32], which suggests that MTEs (stimulus) elicit the "fun" emotion (organism), which ultimately leads to recommendation and revisit intentions (response). Specifically, this research 
has the following four objectives: (1) to identify psychological factors that affect Chinese outbound tourists' MTEs; (2) to investigate the relationships among Chinese outbound tourists' MTEs, positive emotions, such as fun, and their recommendation and revisit intentions; (3) to examine the moderating influence between Chinese outbound tourists' "fun" emotion and positive behavioral intentions; (4) to determine how global destination marketers respond to these experiential factors and risk probability to better position their destinations. Based on these objectives, this study can help international tourist destination marketers establish ongoing relationships with Chinese tourists and ultimately promote their market share and revenue.

\section{Literature Review}

\subsection{S-O-R Model}

The S-O-R model was evolved from a stimulus-response model, and focuses on the mediating role of people's organismic or internal experience between stimuli and response [32]. According to Lee and Yun [33], the S-O-R model consists of three basic elements: stimuli, an organism, and a response. Stimuli usually refers to the external environmental stimuli. The organism is generally considered to be an internal state caused by the external environmental stimuli. The response is the ultimate result and can be categorized into either avoidance or approach behavior. Thus, the S-O-R model assumes that external stimuli (S) influence the internal state $(\mathrm{O})$ and the subsequent behavioral response (R) [32].

While a variety of environmental elements can be considered as external stimuli, experiential elements can act as environmental stimuli, that can elicit tourists' internal states and ultimate behavior. The S-O-R model has been applied in many fields, including retail $[33,34]$ and online consumer behavior [35,36]; however, its application to behavioral intentions based on MTEs in tourism is lacking. Therefore, the model is applied in the present study to capture Chinese outbound tourists' behavioral motivations by examining the relationships among MTEs (S), tourists' internal states, i.e., the "fun" emotion $(\mathrm{O})$, and their subsequent behavioral response, i.e., their recommendation and revisit intentions (R). Therefore, the S-O-R model provides a good theoretical basis for building an integrated model that can reveal the responses of Chinese outbound tourists to their MTEs.

\subsection{Memorable Tourism Experiences (S)}

Pine II and Gilmore [37] proposed the advent of the experience economy era, pointing out that it is the fourth stage of development after the agricultural, industrial, and service economies, and that experiences are unforgettable or memorable occurrences created by consumers. The dimensional composition of tourism experience is an important facet in related research. Sfandla and Bjork [38] constructed a tourism experience network based on value line logic that consists of companies/service providers, consumers/visitors, other elements, and their relationships. Walls et al. [39] discussed the theoretical basis of consumer experience and described the composition of consumer experience in hotels and tourism. They believed that consumer experience includes four components, namely ordinary, extraordinary, cognitive, and emotional experiences, that are helpful to understanding consumer experience in hotel and tourism environments. Pine II and Gilmore [37] proposed four areas of experience: aesthetics, education, entertainment, and escapism.

Kim et al. [40] argued that although early tourism experience-related research has great value, it ignores memorable tourism experiences (MTEs) as an important influencing factor of behavioral intention. MTEs are defined as travel experiences recalled and remembered after an event has occurred, and are selectively constructed based on an individual's assessment [40]. According to Sharma and Nayak [26], MTEs are designed to reinforce and consolidate the recollection of pleasant memories of experiences. Thus, the creation of unforgettable or memorable experiences is valuable for the sustainable development of tourist destinations [41].

Kim et al. [40] proposed a seven-dimensional MTE scale that comprises local culture, hedonism, refreshment, knowledge, meaningfulness, novelty, and involvement. In their qualitative study, 
Tung and Ritchie [42] pointed out that a memorable trip includes four dimensions: expectations, affection, recollection, and consequentiality, while, Kim and Ritchie [43], listed the important dimensions of MTEs as involvement, local culture, hedonism, refreshment, novelty, knowledge, and meaningfulness. Due to the complexity of the essence of MTEs, there is no consensus on the dimensions of MTEs in academic circles, but the understanding of their importance is relatively consistent, i.e., MTEs are considered to be important predictors of tourists' positive behavior [44]. Although MTEs are multi-dimensional structures developed from a variety of factors, this study focuses only on a scale that captures some important psychological experience factors that have been neglected but are worthy of further investigation, namely hedonism, novelty, meaningfulness, and social interaction.

\subsection{Fun $(O)$}

As an expected consumption result, fun may be more related to the concept of customer experience, which emphasizes the pleasure and sensory phenomena in explaining customer behavior in the experience economy [23,37,45]. From the perspective of users and consumers, "fun" as a perception or experience may be especially helpful for products that are enjoyable, rather than having functional values [46]. According to Tasci and Ko [47], fun is defined as an integral part of an object's hedonic value, providing consumers with a desired sensory effect. As a positive emotion that tourists can feel, fun can be regarded as a result of the consumption of products and services driven by experience value [47]. In the field of marketing, much emphasis is placed on experiential factors that can stimulate consumers' hedonic response, which has prompted researchers to consider the role of fun in behavioral intentions [8,45]. In the field of tourism and hospitality, fun may be one of the core elements of the consumer experience, and refers to the joyful experience gained from the aesthetic enjoyment of leisure activities during travel [48]. Previous research has confirmed that positive emotions can be developed by visiting specific destinations [45,49]; therefore, tourist destinations should strive to provide positive emotions for tourists. Tasci and Ko [47] developed four dimensions of positive emotions, namely social vigor, emotional spark, flow, and psychological zest, and the present study adopts emotional spark and flow as the "fun" scale by which to capture tourists' emotional response to the tourism experience. Emotional spark is defined as a high level of an emotional state, including the emotional peak and emotional involvement [47]. Flow, which was originally proposed by Csikszentmihalyi [50], refers to the cognitive state of an individual when he or she is strongly involved in, or focused on, an activity. It manifests as a high concentration of attention, the limiting of consciousness to the activity itself, the loss of self-awareness, the feeling of time moving quickly, and the distortion of the sense of place [50].

The existing tourism literature lacks empirical evidence on how positive emotions, which stem from a specific assessment of benefits [51], are generated. The role of the traveler in generating these emotions is also unclear. Until recently, attention to emotions has not focused on a single, often important, positive emotion, such as fun.

\subsection{Recommendation and Revisit Intentions $(R)$}

Tourists' loyalty has been a prevalent topic in tourism research, and is most commonly measured by the recommendation and revisit intentions of tourists [52]. Chen and Tsai [53] defined tourists' behavioral intention as their judgment on the possibility of revisiting tourist destinations and recommending them to their relatives and friends. Therefore, the recommendation and revisit intentions are important indicators for measuring tourists' loyalty [52].

Recommendation intention is defined as the psychological behavior that encourages family members, colleagues, and friends to use what customers like [31]. If a customer has a pleasant experience while using a product or service, their intent to recommend the product or service to surrounding customers is stronger [54]. It is also a crucial variable in measuring the quality of service in the field of behavioral research, and a key concept that ultimately affects business performance via the acquisition of more customers [55]. Muskat et al. [56] pointed out that loyal customers who have established long-term relationships with service companies and obtained hedonic 
experiences are more motivated to recommend these companies to others, and ultimately contribute to company profits. Recommendation behavior is a positive evaluation of a product, brand, or service that is delivered between consumers through various informal channels without any commercial intention [57]. Day [58] pointed out that customers may turn a neutral or negative attitude into a positive attitude via the recommendation of others, which may have nine times the effect that advertising has. In addition, the development of mobile Internet and social media has maximized the impact of word-of-mouth recommendations; thus, research on these recommendations has received increasing scholarly and industry attention [54]. Consumers' positive recommendations can help companies such as hotels increase revenue from new customers and reduce costs. Those who are willing to establish a positive recommendation for the company are loyal customers [57]. Therefore, the recommendation intention, as an important index of a company's performance, is a meaningful variable that can be used to help predict the company's growth potential and enhance the company's competitiveness. Positive recommendations from tourists with overseas tourism experience can help overseas tourism business marketers gain more potential tourists and create more profits. Therefore, enhancing the recommendation intention of tourists has become an important marketing strategy for tourism industries. This study defines the recommendation intention as the motive of the tourist to make positive verbal recommendations via various channels after travel to an overseas destination.

Revisit intention refers to the possibility of a tourist returning to a tourist destination. As market competition has become increasingly fiercer, the important role of travelers as destination tourists has become an important indicator by which to judge the development potential of the destination [18]. In addition, repeat visitors can bring better cost-effectiveness and economic profit to their destinations. The intention to revisit a place in a certain period after a trip, is the embodiment of loyalty to the destination [59]. Han et al. [60] pointed out that the revisit intention is the likelihood that a customer will revisit a restaurant regardless of whether they had a positive or negative attitude toward the service provider, and it has also been described as the willingness of an individual to visit the same destination again [61]. There have been many studies on the factors that influence tourists' revisit intentions [53], as it is more important to attract more tourists to revisit a destination than to attract new tourists. However, there is a lack of theoretical and empirical research on the mechanism of Chinese outbound tourists' revisit intentions and its relationship with antecedent factors [62]; therefore, this is a topic of common concern for tourism academics and industry practitioners. Identifying the antecedents and generation mechanisms of revisit intention will not only aid in the understanding of the behavioral intentions of tourists, but will also have important significance in the implementation of effective marketing and management strategies for tourist destinations.

\subsection{Perceived Risk}

Perceived risk refers to the perception of risks and uncertainties that tourists may face when choosing a destination [63], and is considered to be the subjective expectation of the loss of an experience; this a biased cognitive assessment of adverse events in tourist destinations and can lead to negative consequences of tourism behavior [64]. Destination risk perception is the attitude of tourists towards the risk perception of tourism related to a specific destination [65]. Perceived travel risk has also been expressed as the attitudes/perceptions of tourists, which depend on their opinions, ideas, and experiences when consuming tourism services [66]. Due to the fact that tourists need to leave their habitual residence and conduct tourism activities in unfamiliar environments, they will encounter many uncertain factors during the tourism process. When tourists make tourism-related decisions, they often tend to recognize whether or not the destination is safe.

Existing literature has shown that tourists' perceptions of destination risk notably affect their destination choices and revisit intentions $[67,68]$, and perceived travel risk has been indicated to have significant impacts on tourist behavior [69]. In addition, Sun [70] has noted that perceived risk has a considerable influence on tourists' attitudes and satisfaction, and Kim et al. [71] indicated that customers will stop purchasing if their total perceived risk exceeds their maximum acceptable level. 
Consequently, tourist destinations with higher perceived risk may experience a decrease in the number of tourists or satisfaction, which will ultimately require the destination to better understand and mitigate the perceived risk to increase tourists' revisit intentions [65]. Although some studies have indicated that perceived risk can affect tourists' satisfaction and revisit intentions $[67,70]$, research has not yet been conducted on whether the relationships among tourists' "fun" emotion and their recommendation and revisit intentions is affected by perceived risk. Therefore, this study uses perceived risk as a moderating variable, and empirically tests the boundary conditions of the influences of the "fun" emotion on the recommendation and revisit intentions.

\section{Research Model and Hypothesis Development}

As presented in Figure 1, the research model in this study was developed based on the S-O-R model, and proposes that tourism experiences, as the stimuli (S), have an impact on tourists' positive emotions, such as fun $(\mathrm{O})$, which influence tourists' recommendation and revisit intentions as response variables (R). In addition, whether there is a moderating effect of perceived risk between the "fun" emotion and recommendation and revisit intentions is empirically investigated.

\section{Memorable Tourism Experiences Positive Emotions Outcome Variables (Stimuli) (Organism) \\ (Response)}

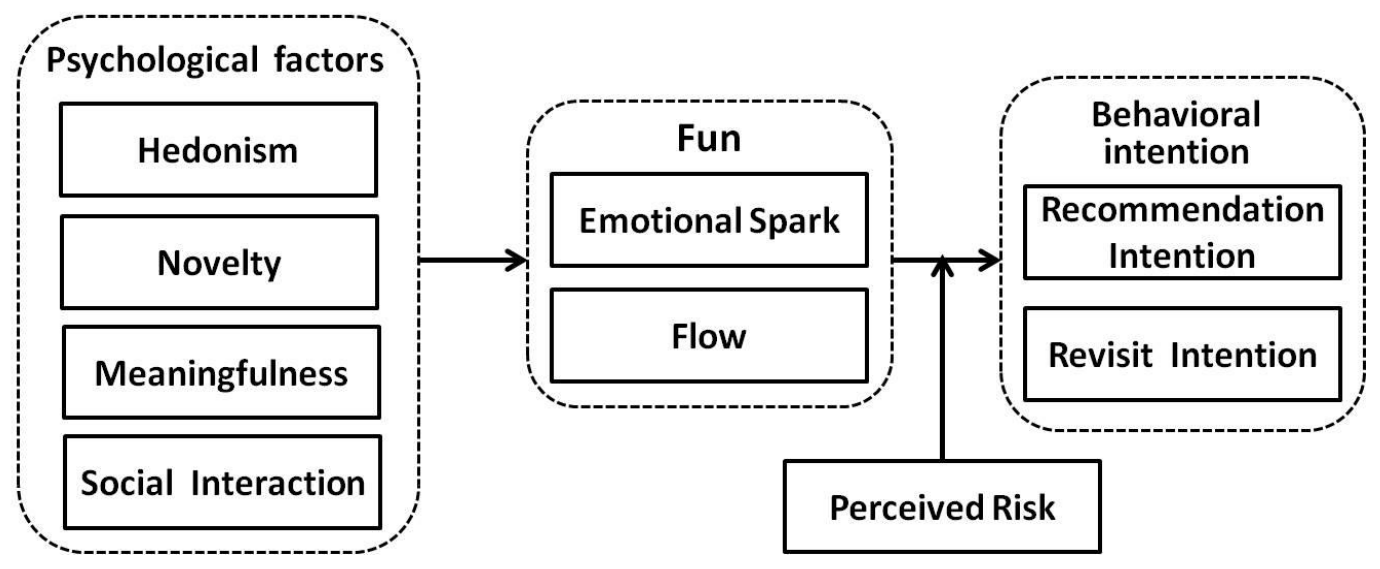

Figure 1. Research model.

\subsection{Impact of Hedonism on Fun}

Hedonism is defined as seeking sensory pleasure [72], and is positively related to feelings of excitement [73], and related to consumers' multi-sensory emotions [45]. Several research works have found that emotions are an integral part of memory, and hedonic experiences have a positive effect $[14,40]$. Hedonism is an integral component of the tourism experience, as it is a key factor in determining tourists' positive emotions and behavioral intentions [74]. Hedonic experiences stimulate the feelings of enjoyment, fantasy, and happiness [14,75]. They are also closely associated with flow and ecstasy, and play central roles an important role in tourist satisfaction, positive emotions, and memory [76]. Tourists obtain positive emotions from hedonic tourism experiences [77], which, as essential elements of the tourism experience, often affect consumers' positive emotions and perceived value [15]. Similarly, "fun" as a positive emotion is also influenced by tourists' hedonic experiences. Therefore, the following hypotheses are established:

Hypothesis 1 (H1). Hedonism experienced at a foreign tourism site is positively related to emotional spark.

Hypothesis 2 (H2). Hedonism experienced at a foreign tourism site is positively related to flow. 


\subsection{Impact of Novelty on Fun}

Novelty refers to a tendency to seek a new experience, and can be understood as tourists' desire to try something unique or new while traveling [78]. According to Lee and Crompton [79], tourism novelty includes four different dimensions: adventure, boredom alleviation, thrill, and surprise. Wei et al. [41] indicated that novelty can be defined as a tendency to change, or as an unexpected experience. Novelty-seeking is a critical factor in the travel motivations of tourists, and affects their emotions and decision-making behavior [80]. Toyama and Yamada [78] found that novelty is positively associated with tourists' delight emotions and satisfaction via an empirical study. In addition, according to Lee et al. [81], tourists' novelty positively impacts their satisfaction and positive emotions, and Kim et al. [17] revealed that novel experiences can amplify tourists' memories of an experience and elicit pleasure. Albaity and Melhem [82] mentioned that if the novelty experienced at a destination exceeds tourists' expectations, they will be happy and satisfied. There are also positive links among novelty, delight, and future behaviors [76]. Thus, providing a novel experience for tourists is critical for tourist destination marketers. Given this view, two hypotheses are proposed as follows:

Hypothesis 3 (H3). Novelty experienced at a foreign tourism site is positively related to emotional spark.

Hypothesis 4 (H4). Novelty experienced at a foreign tourism site is positively related to flow.

\subsection{Impact of Meaningfulness on Fun}

In tourism, meaningfulness is defined as a travel experience of great significance or value $[83,84]$. Kim et al. [17] indicated that meaningfulness can help make memorable experiences and produce positive emotions. People want their lives to be valuable and meaningful, and travel is considered to be an effective way to obtain meaningful experiences [41]. Most tourists hope to obtain pleasure, enjoyment, and excitement during travel, and meaningful travel can elicit positive emotions such as pleasure, delight, and fun [82]. Tsai [44] found that there are positive relationships among meaningfulness, memory, and pleasure emotions. According to Noy [83], meaningfulness can help promote the personal development of tourists. Ali et al. [14] found that if tourists have meaningful feelings during their travel, they will be satisfied and excited, which will ultimately influence their behavioral intentions. A meaningful travel experience can elicit tourists' positive emotions and is positively associated with future behaviors [85]; thus, fun, as a positive emotion, may also be affected by meaningfulness. Given this context, the following hypotheses are put forward:

Hypothesis 5 (H5). Meaningfulness experienced at a foreign tourism site is positively related to emotional spark.

Hypothesis 6 (H6). Meaningfulness experienced at a foreign tourism site is positively related to flow.

\subsection{Impact of Social Interaction on Fun}

Liu [86] defined social interaction as the desire to seek an emotional connection when an individual meets local travel partners. Lin et al. [87] found that tourist-to-tourist interaction not only positively affects perceived cohesion and intimacy, but can also help establish high-quality experiences. Social interaction, a fundamental element of memorable experiences, is conducive to the preservation of tourists' long-term memory [12]. Lee and Han [88] found that interaction quality is an important factor that affects consumers' emotions and satisfaction. In addition, several studies have explored the relationship between consumers' interactions with others and their satisfaction, and have found that interaction with others is closely linked with positive emotions and satisfaction $[39,89,90]$. Ali et al. [91] investigated the effects of interaction with consumers and staff on individuals' emotions in the context of theme parks. Moreover, Bilro et al. [92] also found that interaction with others can affect individuals' 
emotions, such as pleasure, excitement, and satisfaction. Although the relationships between social interaction and emotion have been examined and confirmed, research on the influence of social interaction on a single specific emotion, such as fun, is relatively scarce, especially in the field of tourism. Thus, this study focuses on the relationship between social interaction and fun, and, therefore, the following hypotheses are formulated:

Hypothesis 7 (H7). Social interaction experienced at a foreign tourism site is positively related to emotional spark.

Hypothesis 8 (H8). Social interaction experienced at a foreign tourism site is positively related to flow.

\subsection{Impact of Fun on Recommendation and Revisit Intentions}

Tasci and Ko [47] defined fun as a significant component of an object's hedonic value, and developed it from the perspectives of four dimensions: emotional spark, flow, social vigor, and psychological zest. The present research uses flow and emotional spark as the scale with which to capture tourists' behavioral intentions that are influenced by fun. Litvin et al. [52] revealed that recommendation and revisit intentions are important indicators with which to measure tourists' loyalty. There is a need to examine the mechanism by which positive emotions elicit behavioral intentions [91]. Thus, the relationships among the "fun" emotion and recommendation and revisit intentions are investigated in the present study.

According to Choi and Choi [22], tourists' "fun" emotions have a significant influence on their on-the-spot behaviors. If tourists have positive feelings during their travel, their desire to recommend the destination to others will be stronger [93]. Several studies have discussed the effects of positive emotions on satisfaction and recommendation intention [94,95], and it has been indicated that customers' positive emotions, such as pleasure and excitement, have notable influences on their future behaviors. Ali et al. [91] examined and confirmed that tourists' positive emotions, such as delight, have significant impacts on their satisfaction and loyalty in the context of theme parks. Ryu et al. [96] indicated that emotional response substantially affects tourists' satisfaction and their willingness to revisit a destination. Mattila and Enz [97] found that customers' positive emotions are closely associated with their satisfaction and behavioral intentions. Similarly, fun, as one of the positive emotions, can also affect behavioral intentions. Hence, the following hypotheses are proposed:

Hypothesis 9 (H9). Emotional spark is positively related to recommendation intention.

Hypothesis 10 (H10). Emotional spark is positively related to revisit intention.

Hypothesis 11 (H11). Flow is positively related to recommendation intention.

Hypothesis 12 (H12). Flow is positively related to revisit intention.

\subsection{The Moderating Role of Perceived Risk}

Perceived risk reflects the risks and uncertainties that tourists may face when choosing a tourist destination, and is an important factor that affects tourists' perceptions and attitudes towards a tourist destination. As tourism activities are conducted in non-conventional environments, the off-site nature of these activities and the intangibility of products increase their risks [67].

Sharifpour et al. [68] found that tourists with low perceived risk are more likely to recommend destinations to friends and relatives than tourists with high perceived risk are. Jin et al. [98] indicated that perceived risk has negative impacts on consumer trust, satisfaction and loyalty in the context of upscale restaurants. When tourists have a high perceived risk during travel, their perceived value and satisfaction will decrease, which will affect their willingness to revisit a destination [65]. Tourists' 
perceptions of the risk of a destination will affect their satisfaction and attitudes toward revisiting, which will in turn affect their revisit behavior [67]. In addition, Campbell and Goodstein [99] indicated that the perceived risk of consumers has a moderating role in the evaluation of products, and their research suggests that a high perceived risk will cause consumers to become more conservative; on the contrary, when perceived risk is low, customers will evaluate the product or service more positively. Therefore, perceived risk moderates consumer evaluation of a product [99]. In addition, perceived travel risk is indicated to have significant impacts on tourist behavior [69], and when perceived destination risk is high, tourists will have lower satisfaction and a bad impression of the destination [70]. Tourists' perception of risk is key factor that affects their revisit and recommendation intentions. Therefore, while tourist destination managers strive to provide tourists with an unforgettable experience, they should take perceived risk into consideration, to increase the tourists' revisit intentions and achieve sustainable development. Based on these views, the following hypotheses are established:

Hypothesis 13 (H13). Perceived risk will moderate the relationship between emotional spark and recommendation intention, such that the emotional spark-recommendation intention path will be weaker when the perceived risk is high rather than low.

Hypothesis 14 (H14). Perceived risk will moderate the relationship between emotional spark and revisit intention, such that the emotional spark-revisit intention path will be weaker when the perceived risk is high rather than low.

Hypothesis 15 (H15). Perceived risk will moderate the relationship between flow and recommendation intention, such that the flow-recommendation intention path will be weaker when the perceived risk is high rather than low.

Hypothesis 16 (H16). Perceived risk will moderate the relationship between flow and revisit intention, such that the flow-revisit intention path will be weaker when the perceived risk is high rather than low.

\section{Research Method}

\subsection{Sampling Design and Data Collection}

The target population of this research was Chinese tourists over 18 years of age who have experienced overseas tourism in the last two years. Respondents answered questionnaire items based on their experiences of outbound travel. Existing research has noted that due to economic development, convenient transportation, and high income levels, Chinese outbound tourists are mainly non-agricultural adults in major cities [1]. Thus, China's six major cities, including the three first-tier cities of Shanghai, Guangzhou, and Beijing, and the three second-tier cities of Shijiazhuang, Jinan, and Harbin, were selected. In addition, to obtain the sample data, field interception was adopted, and international airports, cruise terminals, large shopping plazas, and high-end residential areas were selected for the administration of the field survey.

The survey began on 30 July 2019 and ended on 15 December 2019. To ensure the questionnaire validity, each item was specifically explained before distribution. The entire data collection process was monitored to maintain a balance of demographic characteristics including income, age, and education level. In total, 560 questionnaires were distributed, 508 of which were returned, and every respondent was given a gift to express the researchers' gratitude. After removing questionnaires with the same numbers for answers or an excess of blank responses, 413 valid questionnaires were ultimately obtained.

\subsection{Measurement Development}

In this study, multi-item scales were designed for proposed constructs according to the following procedure. First, each construct and its measurement scales were adapted from the existing literature 
to meet the research theme and purpose. Due to the fact that questionnaire items in previous research were originally written in English, a professional translator translated them into Chinese. To ensure the accuracy of the translation, another professional translator conducted a reverse back-translation. Then, after the preliminary design of the questionnaire, a pre-survey was conducted on four professors of tourism management and 40 consumers who had experience with overseas travel. Then, based on the pre-survey results, the questionnaire was further revised and improved. Finally, 31 items for nine constructs were selected based on the literature review and practical research.

Hedonism and novelty were measured using three and four items, which were respectively adapted from Wei et al. [41] and Kim et al. [40]. Meaningfulness was measured using three items developed by Kim et al. [40] and Kim et al. [17], and three items for social interaction were adapted from Wei et al. [41]. Emotional spark was measured using three items developed by Tasci and Ko [47], and three items for the measurement of flow were modified from Choi and Choi [22]. Recommendation intention was measured using four items developed by Chang et al. [57], and revisit intention was measured using three items adapted from Wu et al. [100] Perceived risk was measured using five items developed by Fuchs and Reichel [101]. The seven-point Likert scale, which ranges from completely disagree (1) to completely agree (7), was used for all measurements.

\subsection{Data Analysis}

The model in this study was validated using structural equation modeling (SEM), the advantage of which is that both the estimation of the measurement model and the evaluation of the structural model are considered. AMOS 24.0 was employed to evaluate the measurement and structural models. If the indicator chosen for a construct does not measure the construct, testing the structural model will be meaningless [102]; thus, a two-step modeling approach recommended by McDonald and Ho [103] was adopted. Confirmatory factor analysis (CFA) was first performed to assess the construct reliability and validity, followed by SEM analysis to estimate the structural model and path effects.

\subsection{Profile of Respondents}

The demographic profile of the sample set is presented in Table 1. The respondents were balanced in gender, with males accounting for $47.2 \%$ and females accounting for $52.8 \%$. The majority of the sample set $(85.3 \%)$ were between the ages of 16 and 40 , and most respondents were at least college-educated $(88.9 \%)$. The proportion of young people among the respondents was higher than that of old people. However, considering that these respondents are a major component of China's outbound tourism market, the sample was considered to be suitable for this study. In addition, the sample set included a wide range of occupations (e.g., students, managers, civil servants, teachers, clerks/white-collar workers, blue-collar workers), and the majority of their monthly incomes were diverse. 
Table 1. Demographic profile $(\mathrm{N}=413)$.

\begin{tabular}{|c|c|c|c|c|c|}
\hline Demographic & Frequency & Percentage & Demographic & Frequency & Percentage \\
\hline Gender & & & \multicolumn{3}{|l|}{ Education } \\
\hline Male & 195 & 47.2 & High school or below & 46 & 11.1 \\
\hline Female & 218 & 52.8 & Bachelor's degree & 203 & 19.2 \\
\hline Age (years) & & & Master's degree or above & 164 & 39.7 \\
\hline $16-20$ & 45 & 10.9 & \multicolumn{3}{|l|}{ Monthly income (RMB) } \\
\hline $21-30$ & 151 & 36.6 & $<2000$ & 23 & 5.6 \\
\hline $31-40$ & 156 & 37.8 & $2001-4000$ & 35 & 8.5 \\
\hline $41-50$ & 34 & 8.2 & $4001-6000$ & 106 & 25.7 \\
\hline $51-60$ & 20 & 4.8 & $6001-8000$ & 119 & 28.8 \\
\hline$>60$ & 7 & 1.7 & $8001-1000$ & 51 & 12.3 \\
\hline Occupation & & & $>10,001$ & 79 & 19.1 \\
\hline Student & 21 & 501 & \multicolumn{3}{|c|}{ Overseas travel experience (number of times) } \\
\hline Manager or above & 40 & 9.7 & 1 & 117 & 28.3 \\
\hline Civil servant & 126 & 30.5 & $2-3$ & 181 & 43.8 \\
\hline Teacher & 71 & 17.2 & 4 or more & 115 & 27.8 \\
\hline Clerk/white-collar & 95 & 23.0 & & & \\
\hline Blue-collar worker & 35 & 8.5 & & & \\
\hline Others & 25 & 6.0 & & & \\
\hline
\end{tabular}

\section{Analysis Results}

\subsection{Measurement Model}

\subsubsection{Reliability Analysis}

Before verifying the hypotheses, reliability was first tested to ensure the appropriateness of the research tool. Cronbach's $\alpha$ was used to evaluate the internal consistency of each construct. Regarding the acceptable level, Nunnally [104] proposed that a Cronbach's $\alpha$ value greater than 0.9 indicates high reliability, while $0.7<\alpha<0.9$ indicates medium reliability. The reliability of each construct in this study was between 0.783 and 0.910 . Therefore, the questionnaire used in this study had good reliability. The results are presented in Table 2. 
Table 2. Scale items and reliability analysis.

\begin{tabular}{|c|c|c|}
\hline Construct & Item & Cronbach's $\alpha$ \\
\hline Hedonism & $\begin{array}{l}\text { HED1. I was thrilled about having a new experience at this destination. } \\
\text { HED2. I felt very excited during this trip. } \\
\text { HED3. I indulged in activities during this trip. }\end{array}$ & 0.783 \\
\hline Novelty & $\begin{array}{l}\text { NOY1. I came across new things during this trip. } \\
\text { NOY2. This trip was a unique experience. } \\
\text { NOY3. It was not the same as my previous travel experience. } \\
\text { NOY4. I had a once-in-a-lifetime experience. }\end{array}$ & 0.884 \\
\hline Meaningfulness & $\begin{array}{l}\text { MEA1. I did something meaningful during this trip. } \\
\text { MEA2. I did something important during this trip. } \\
\text { MEA3. I discovered myself during this trip. }\end{array}$ & 0.861 \\
\hline $\begin{array}{c}\text { Social } \\
\text { interaction }\end{array}$ & $\begin{array}{l}\text { SOI1. My relationship with my peers has progressed. } \\
\text { SOI2. I made new friends at this destination. } \\
\text { SOI3. I integrated into a group. }\end{array}$ & 0.823 \\
\hline $\begin{array}{l}\text { Emotional } \\
\text { spark }\end{array}$ & $\begin{array}{l}\text { EMS1. My visit to this place provided emotional peaks. } \\
\text { EMS2. My visit to this place made me feel emotionally involved. } \\
\text { EMS3. My visit to this place made me feel emotionally charged. }\end{array}$ & 0.849 \\
\hline Flow & $\begin{array}{l}\text { FLO1. My visit to this place made me forget about my daily routine. } \\
\text { FLO2. My visit to this place helped me forget about the time. } \\
\text { FLO3. I was totally absorbed in this trip. }\end{array}$ & 0.830 \\
\hline $\begin{array}{l}\text { Recommendation } \\
\text { intention }\end{array}$ & $\begin{array}{l}\text { REC1. I would suggest this place to anyone who intends to travel there. } \\
\text { REC2. I would tell my relatives, friends, and colleagues about the } \\
\text { advantages of this place. } \\
\text { REC3. I would be happy to recommend this place to my relatives, } \\
\text { friends, and colleagues. } \\
\text { REC4. I would share my experiences of this trip on social media. }\end{array}$ & 0.820 \\
\hline $\begin{array}{l}\text { Revisit } \\
\text { intention }\end{array}$ & $\begin{array}{l}\text { REV1. If I could, I would come to this place again. } \\
\text { REV2. I will always consider this place to be my first destination choice. } \\
\text { REV3. I have a strong intention to visit this place again. }\end{array}$ & 0.853 \\
\hline $\begin{array}{l}\text { Perceived } \\
\text { risk }\end{array}$ & $\begin{array}{l}\text { PER1. I worried about crime (theft, pickpockets, robbery) and terrorism } \\
\text { in this destination. } \\
\text { PER2. I worried about getting injured during this trip. } \\
\text { PER3. I worried that this trip would involve unexpected extra expenses } \\
\text { (such as extra costs in hotels and changes in exchange rates). } \\
\text { PER4. I worried that I would not receive good value for my money. } \\
\text { PER5. I worried that I would encounter communication barriers during } \\
\text { this trip. }\end{array}$ & 0.910 \\
\hline
\end{tabular}

\subsubsection{Convergent Validity}

The convergent and discriminant validities of the measurement model were examined via confirmatory factor analysis (CFA). The measurement model showed an acceptable fit $\left(X^{2}=780.913\right.$ $\left.(\mathrm{df}=398), \mathrm{X}^{2} / \mathrm{df}=1.962, \mathrm{CFI}=0.950, \mathrm{NFI}=0.904, \mathrm{NNFI}=0.941, \mathrm{SRMR}=0.047, \mathrm{RMSEA}=0.048\right)$, and Table 3 summarizes the standardized and unstandardized factor loadings, significance test results, composite reliability (CR), standard errors, and average variance extracted (AVE). The three indicators developed by Fornell and Larcker [105] for the evaluation of the convergent validity of a measurement item are (a) the reliability or squared multiple correlation of each measurement item, (b) the composite reliability, and (c) the AVE.

As exhibited in Table 3, the standardized factor loadings for all items were between 0.668 and 0.881 , which is a reasonable range. The composite reliability of all constructs ranged from 0.783 to 0.893, therefore exceeding the value of 0.7 recommended by Nunnally and Bernstein [106]. Finally, the average variance extracted (AVE) of all constructs ranged from 0.535 to 0.680 ; these values are all greater than $0.5[105,107]$, indicating that all constructs had sufficient convergent validity. 
Table 3. Results of confirmatory factor analysis.

\begin{tabular}{|c|c|c|c|c|c|c|c|c|c|}
\hline \multirow{2}{*}{ Construct } & \multirow{2}{*}{ Item } & \multicolumn{4}{|c|}{ Significance of Estimated Parameters } & \multicolumn{2}{|c|}{ Item Reliability } & \multirow{2}{*}{$\begin{array}{c}\begin{array}{c}\text { Construct } \\
\text { Reliability }\end{array} \\
\text { CR }\end{array}$} & \multirow{2}{*}{$\begin{array}{c}\begin{array}{c}\text { Convergent } \\
\text { Validity }\end{array} \\
\text { AVE }\end{array}$} \\
\hline & & Unstd. & S.E. & Unstd./S.E. & $p$-Value & Std. & SMC & & \\
\hline \multirow{3}{*}{ Hedonism } & HED1 & 1.000 & & & & 0.747 & 0.558 & 0.783 & 0.546 \\
\hline & HED2 & 0.993 & 0.072 & 13.877 & 0.000 & 0.754 & 0.569 & & \\
\hline & HED3 & 0.947 & 0.071 & 13.390 & 0.000 & 0.716 & 0.513 & & \\
\hline \multirow{4}{*}{ Novelty } & NOY1 & 1.000 & & & & 0.848 & 0.719 & 0.887 & 0.662 \\
\hline & NOY2 & 0.993 & 0.047 & 21.301 & 0.000 & 0.844 & 0.712 & & \\
\hline & NOY3 & 0.964 & 0.049 & 19.667 & 0.000 & 0.824 & 0.679 & & \\
\hline & NOY4 & 0.797 & 0.048 & 16.453 & 0.000 & 0.733 & 0.537 & & \\
\hline \multirow{3}{*}{ Meaningfulness } & MEA1 & 1.000 & & & & 0.807 & 0.651 & 0.864 & 0.680 \\
\hline & MEA2 & 1.024 & 0.055 & 18.577 & 0.000 & 0.881 & 0.776 & & \\
\hline & MEA3 & 0.935 & 0.056 & 16.626 & 0.000 & 0.783 & 0.613 & & \\
\hline \multirow{3}{*}{ Social interaction } & SOI1 & 1.000 & & & & 0.713 & 0.508 & 0.826 & 0.613 \\
\hline & SOI2 & 1.336 & 0.090 & 14.877 & 0.000 & 0.810 & 0.656 & & \\
\hline & SOI3 & 1.373 & 0.094 & 14.640 & 0.000 & 0.822 & 0.676 & & \\
\hline \multirow{3}{*}{ Emotional spark } & EMS1 & 1.000 & & & & 0.747 & 0.558 & 0.854 & 0.662 \\
\hline & EMS2 & 1.181 & 0.074 & 15.872 & 0.000 & 0.834 & 0.696 & & \\
\hline & EMS3 & 1.168 & 0.071 & 16.420 & 0.000 & 0.856 & 0.733 & & \\
\hline \multirow{3}{*}{ Flow } & FLO1 & 1.000 & & & & 0.668 & 0.446 & 0.840 & 0.639 \\
\hline & FLO2 & 1.600 & 0.108 & 14.810 & 0.000 & 0.862 & 0.743 & & \\
\hline & FLO3 & 1.670 & 0.115 & 14.494 & 0.000 & 0.853 & 0.728 & & \\
\hline \multirow{4}{*}{$\begin{array}{l}\text { Recommendation } \\
\text { intention }\end{array}$} & REC1 & 1.000 & & & & 0.672 & 0.452 & 0.821 & 0.535 \\
\hline & REC2 & 1.083 & 0.082 & 13.207 & 0.000 & 0.726 & 0.527 & & \\
\hline & REC3 & 1.217 & 0.100 & 12.204 & 0.000 & 0.787 & 0.619 & & \\
\hline & REC4 & 1.212 & 0.108 & 11.263 & 0.000 & 0.737 & 0.543 & & \\
\hline \multirow{3}{*}{ Revisit intention } & REV1 & 1.000 & & & & 0.853 & 0.728 & 0.854 & 0.660 \\
\hline & REV2 & 0.840 & 0.048 & 17.480 & 0.000 & 0.787 & 0.619 & & \\
\hline & REV3 & 0.899 & 0.052 & 17.254 & 0.000 & 0.796 & 0.634 & & \\
\hline \multirow{5}{*}{ Perceived risk } & PER1 & 1.000 & & & & 0.852 & 0.726 & 0.893 & 0.627 \\
\hline & PER2 & 0.838 & 0.048 & 17.354 & 0.000 & 0.721 & 0.520 & & \\
\hline & PER3 & 0.900 & 0.051 & 17.634 & 0.000 & 0.824 & 0.679 & & \\
\hline & PER4 & 1.012 & 0.052 & 19.453 & 0.000 & 0.808 & 0.653 & & \\
\hline & PER5 & 0.847 & 0.051 & 16.667 & 0.000 & 0.746 & 0.557 & & \\
\hline
\end{tabular}

Note. Unstd.: unstandardized factor loadings; Std: standardized factor loadings; SMC: square multiple correlations; CR: composite reliability; AVE: average variance extracted.

\subsubsection{Discriminant Validity}

Discriminant validity is used to compare the square root of the AVE of a construct with the correlations between each construct and others [105]. If the square root of the construct's AVE is larger than the off-diagonal elements in the corresponding rows and columns, these indicators are more closely related to the construct than to other indicators.

As presented in Table 4, the square roots of the on-diagonal AVE scores were greater than the off-diagonal values, thus providing sufficient evidence of discriminant validity. 
Table 4. Discriminant validity results.

\begin{tabular}{cccccccccc}
\hline & HED & NOY & MEA & SOI & EMS & FLO & REC & REV & PER \\
\hline HED & $\mathbf{0 . 7 3 9}$ & & & & & & & & \\
NOY & 0.701 & $\mathbf{0 . 8 1 4}$ & & & & & & & \\
MEA & 0.296 & 0.229 & $\mathbf{0 . 8 2 5}$ & & & & & & \\
SOI & 0.666 & 0.684 & 0.150 & $\mathbf{0 . 7 8 3}$ & & & & & \\
EMS & 0.682 & 0.642 & 0.317 & 0.660 & $\mathbf{0 . 8 1 4}$ & & & & \\
FLO & 0.706 & 0.710 & 0.324 & 0.707 & 0.639 & $\mathbf{0 . 7 9 9}$ & & & \\
REC & 0.406 & 0.381 & 0.180 & 0.400 & 0.448 & 0.470 & $\mathbf{0 . 7 3 1}$ & & \\
REV & 0.343 & 0.321 & 0.152 & 0.337 & 0.382 & 0.394 & 0.709 & $\mathbf{0 . 8 1 2}$ & \\
PER & 0.135 & 0.142 & 0.125 & 0.102 & 0.126 & 0.156 & 0.205 & 0.198 & $\mathbf{0 . 7 9 2}$
\end{tabular}

Note. The on-diagonal items in bold represent the square roots of the AVE; off-diagonal elements are the correlation estimates; HED: hedonism; NOY: novelty; MEA: meaningfulness; SOI: social interaction; EMS: emotional spark; FLO: flow; REC: recommendation intention; REV: revisit intention; PER: perceived risk.

\subsection{Structural Model Analysis}

The maximum likelihood method was used for structural model testing, to estimate the hypothetical relationship of the proposed model. The evaluation results of the model fit indicators indicate that the model fit was generally good $\left(\mathrm{X}^{2}=713.422(\mathrm{df}=280), \mathrm{X}^{2} / \mathrm{df}=2.548, \mathrm{CFI}=0.930\right.$, $\mathrm{GFI}=0.890, \mathrm{NNFI}=0.918, \mathrm{SRMR}=0.078, \mathrm{RMSEA}=0.061$ )

Table 5 presents the path coefficient results. Hedonism was found to have a significant positive effect on both emotional spark ( $\beta=0.301, p=0.001)$ and flow $(\beta=0.339, p<0.001)$; thus, $\mathrm{H} 1$ and $\mathrm{H} 2$ are supported. Novelty was found to significantly influence both emotional spark $(\beta=0.169, p=0.035)$ and flow $(\beta=0.156, p=0.032)$; therefore, $\mathrm{H} 3$ and $\mathrm{H} 4$ are supported. Meaningfulness was found to be positively related to emotional spark $(\beta=0.141, p=0.003)$ and flow $(\beta=0.127, p=0.003)$; hence, $\mathrm{H} 5$ and $\mathrm{H} 6$ are supported. Social interaction was found to have significant effects on both emotional spark $(\beta=0.323, p<0.001)$ and flow $(\beta=0.405, p<0.001)$; thus, H7 and H8 are supported. Emotional spark was found to be positively correlated with recommendation intention $(\beta=0.249, p=0.003)$ and revisit intention $(\beta=0.220, p=0.009)$, and flow was found to significantly influence recommendation intention $(\beta=0.311, p<0.001)$ and revisit intention $(\beta=0.253, p=0.003)$; therefore, H9, H10, H11, and H12 are supported.

Table 5. Hypothesis testing.

\begin{tabular}{cccccccc}
\hline DV & IV & Unstd & S.E. & t-Value & $p$-Value & Std. & Result \\
\hline \multirow{2}{*}{ EMS } & HED & 0.347 & 0.105 & 3.292 & 0.001 & 0.301 & Supported \\
& NOY & 0.132 & 0.063 & 2.105 & 0.035 & 0.169 & Supported \\
& MEA & 0.131 & 0.044 & 2.981 & 0.003 & 0.141 & Supported \\
& SOI & 0.378 & 0.091 & 4.144 & 0.000 & 0.323 & Supported \\
\hline \multirow{2}{*}{ FLO } & HED & 0.274 & 0.068 & 4.042 & 0.000 & 0.339 & Supported \\
& NOY & 0.085 & 0.040 & 2.143 & 0.032 & 0.156 & Supported \\
& MEA & 0.083 & 0.028 & 2.937 & 0.003 & 0.127 & Supported \\
& SOI & 0.333 & 0.060 & 5.516 & 0.000 & 0.405 & Supported \\
\hline \multirow{2}{*}{ REC } & EMS & 0.171 & 0.058 & 2.936 & 0.003 & 0.249 & Supported \\
& FLO & 0.305 & 0.084 & 3.633 & 0.000 & 0.311 & Supported \\
\hline \multirow{2}{*}{ REV } & EMS & 0.265 & 0.102 & 2.605 & 0.009 & 0.220 & Supported \\
& FLO & 0.435 & 0.145 & 2.990 & 0.003 & 0.253 & Supported \\
\hline
\end{tabular}

Note. HED: hedonism; NOY: novelty; MEA: meaningfulness; SOI: social interaction; EMS: emotional spark; FLO; flow; REC: recommendation intention; REV: revisit intention; PER: perceived risk.

\subsection{The Moderating Effects of Perceived Risk}

To verify the moderating effects of tourists' perceived risk, the samples were first divided into high- and low-risk groups. Pairwise parameter comparisons were then performed to identify the 
difference and significance of the path coefficients (standardized coefficient and $t$-value) between the variables of the two groups, and the path estimates are presented in Table 6.

Table 6. Comparison between low-risk and high-risk groups.

\begin{tabular}{|c|c|c|c|c|c|c|}
\hline \multirow{2}{*}{$\begin{array}{l}\text { Hypothesis } \\
\text { (Paths) }\end{array}$} & \multicolumn{2}{|c|}{ Low-Risk Group } & \multicolumn{2}{|c|}{ High-Risk Group } & \multirow{2}{*}{$\begin{array}{c}\text { C.R. for } \\
\text { Differences }\end{array}$} & \multirow[b]{2}{*}{ Results } \\
\hline & $\begin{array}{l}\text { Standardized } \\
\text { Coefficient }\end{array}$ & t-Value & $\begin{array}{l}\text { Standardized } \\
\text { Coefficient }\end{array}$ & t-Value & & \\
\hline EMS $\rightarrow$ REC & 0.594 & $2.934^{* *}$ & 0.163 & $2.145 *$ & 2.531 & Supported \\
\hline $\mathrm{EMS} \rightarrow \mathrm{REV}$ & 0.602 & $3.142 * * *$ & 0.157 & $2.015 * *$ & 2.658 & Supported \\
\hline $\mathrm{FLO} \rightarrow \mathrm{REC}$ & 0.645 & $4.362 * * *$ & 0.193 & $2.574^{*}$ & 2.211 & Supported \\
\hline $\mathrm{FLO} \rightarrow \mathrm{REV}$ & 0.482 & $2.876^{* *}$ & 0.325 & $3.022 * *$ & 1.243 & Not supported \\
\hline
\end{tabular}

Note. EMS: emotional spark; FLO: flow; REC: recommendation intention; REV: revisit intention; PER: perceived risk; $: p<0.05, * *: p<0.01, * * *: p<0.001$.

The positive influence of emotional spark on recommendation intention was found to be greater in the low-risk group $(\beta=0.594, \mathrm{t}$-value $=2.934, p<0.01)$ than in the high-risk group $(\beta=0.163, \mathrm{t}$-value $=$ $2.145, p<0.05)$, and the difference between the path coefficients of the two groups was also significant $($ C.R. $=2.531)$, thus, H13 is supported. Similarly, the positive impact of emotional spark on revisit intention was found to be greater in the low-risk group $(\beta=0.602$, $\mathrm{t}$-value $=3.142, p<0.001)$ than in the high-risk group $(\beta=0.157$, $\mathrm{t}$-value $=2.015, p<0.01)$, and the difference between the path coefficients of the two groups was also significant $(C . R .=2.658)$; therefore, H14 is supported.

In addition, the positive effect of flow on recommendation intention was found to be greater in the low-risk group $(\beta=0.645, \mathrm{t}$-value $=4.362, p<0.001)$ than in the high-risk group $(\beta=0.193, \mathrm{t}$-value $=$ $2.574, p<0.05)$, and the difference between the path coefficients of the two groups was also significant $(C . R .=2.211)$, thus, $\mathrm{H} 15$ is supported. Moreover, the positive impact of flow on revisit intention was found to be greater in the low-risk group $(\beta=0.482$, $\mathrm{t}$-value $=2.876, p<0.01)$ than in the high-risk group $(\beta=0.325$, $\mathrm{t}$-value $=3.022, p<0.01)$; however, the difference between the path coefficients of the two groups was not significant (C.R. $=1.243)$. Therefore, H16 is not supported, which indicates that the moderating effect of perceived risk on the causal relationship between flow and revisit intention is not supported.

\section{Discussion and Conclusions}

In response to the call for tourism-related research $[4,8]$ on the development of integrated models, the primary goal of this study was to establish a causal relationship model among the memorable experiential elements of Chinese outbound tourists, positive emotional responses, and behavioral intentions based on the S-O-R model. Moreover, the theoretical results related to tourism experience were expanded, and consistent with the results of marketing-related research [13]; the important roles of psychological experiential elements and emotions in behavioral prediction in today's experience economy era were emphasized. Previous studies have used an integrated perspective to analyze the elements of MTEs [15,26], whereas this study only analyzed the important psychological factors that affect unforgettable tourism experiences. Based on the existing research on MTEs [40,41], four factors, namely hedonism, novelty, meaningfulness, and social interaction, were considered to be important psychological factors that shape MTEs, and their impacts on tourists' positive emotions and behavioral intentions were examined. The proposed model was used in this research to examine the relationships between (a) memorable experiential elements, such as hedonism, novelty, meaningfulness, social interaction, and perceived positive emotions such as fun, (b) the "fun" emotion and recommendation intention, (c) the "fun" emotion and revisit intention, and (d) the "fun" emotion, perceived risk, and recommendation and revisit intentions. The results demonstrated that creating MTEs can stimulate tourists' positive emotional reactions, such as fun, which ultimately affect their behavioral intentions. This indicates that high levels of hedonism, novelty, meaningfulness, and social interaction experienced by tourists at destinations will effectively stimulate positive emotions, further motivating their strong 
recommendation and revisit intentions. These results not only expand Kim's [40] research, but also enrich the theoretical results related to the tourism experience [8], and respond well to the call for research on the correlation between unforgettable or memorable tourism experiences and their outcome effects [108].

Empirical research on the verification of MTEs, emotional responses, and behavioral intentions remains very scarce, as more research focus has been placed on the construction of tourist destination facilities and their image improvement [28,53], ignoring the personal feelings of tourists as human beings. With continued economic growth and the improvement of living conditions, compared with sightseeing tours, current tourists pay more attention to the tourism experience, and hope to obtain a unique and memorable experience during travel, as well as to pursue emotional pleasure and enjoyment [31]. Consequently, this study has explored the antecedents of MTEs and the relationships among memorable experiential components, the "fun" emotion, and behavioral intentions. The findings confirm that the psychological experiential elements of hedonism, novelty, meaningfulness, and social interaction positively influence tourists' positive emotions, such as fun (H1 to H8). This indicates that when tourists perceive a high level of hedonism, a unique experience, a meaningful experience, and a high-quality interaction, they will feel the "fun" emotion and behave positively, and tourist destinations could benefit from these positive behaviors (i.e., the recommendation of this destination to others and revisiting this destination). Thus, it is very important to maintain a competitive destination image, and creating unforgettable or memorable experiences for tourists is crucial for tourist destinations to enhance their core competitiveness in today's strongly competitive environment.

With the dawn of the experience economy and the improvement of consumers' status, compared with functional consumption, consumers are more often pursuing hedonic value, hoping to obtain emotional pleasure and satisfaction [25]. A significant amount of research has been carried out on tourists' motivations [8,24], but has ignored the important influence of tourists' emotions on their future behavior. This study confirmed the significant relationship between tourists' positive emotions (i.e., fun) and their positive behavioral intentions (i.e., recommendation and revisit intentions, H9 to H12), and the findings are consistent with those of previous research [35]. Hence, tourist destinations should create tourism experiences that can elicit positive emotions and positive behaviors from tourists to enhance their competitiveness. These findings all contribute significantly to prior research by providing important empirical evidence of the effects of MTEs on positive emotional responses and behavioral intentions in the field of overseas tourism.

In addition, the boundary conditions for the relationship between the "fun" emotion and recommendation and revisit intentions were examined. The results revealed that perceived risk has negative moderating effects on the relationships between (a) emotional spark and recommendation intention, (b) emotional spark and revisit intention, and (c) flow and recommendation intention. However, the moderating effect on the causal relationship between tourists' flow and their revisit intention was not confirmed, which may have been because most of the survey respondents $(85.3 \%)$ were young people under 40 years of age. Relevant research has pointed out that the new generation of young people is in greater pursuit of high-quality, personalized, and unique experiences [12]. When tourists are able to enjoy a flow experience during a trip, they will be immersed in it, forget the time, have a strong sense of pleasure, and become less sensitive to risk perception. Even if the perceived risk exists, the perceived gain is far greater than the perceived loss, and it will not affect their willingness to revisit the destination. Therefore, the role of perceived risk in moderating flow and revisit intention is not significant. It is necessary to construct a study with more diverse samples in the future, and to again verify the moderating effect.

\subsection{Theoretical Implications}

This research has important theoretical implications. First, four important psychological factors, namely hedonism, novelty, meaningfulness, and social interaction, that influence MTEs in the context of Chinese outbound tourists were identified. These results further subdivide and validate the 
important influencing factors of MTEs, and provide important theoretical evidence for capturing tourism motivation more accurately.

Secondly, the application field of the S-O-R model, which has previously primarily focused on the fields of psychology and sociology, was extended to the field of tourism, and the theoretical results of the S-O-R theory were enriched.

Thirdly, a causal relationship model among MTEs of Chinese outbound tourists, positive emotional responses (i.e., fun), and behavior (i.e., recommendation and revisit intentions) was developed. Some tourism experience-related research has indicated that tourism experience has notable influences on tourist satisfaction, which significantly influences their behavioral intentions [31]. However, some studies argue that the impacts of MTEs as the frontier of tourism experience on satisfaction and revisit intention are more significant, and future studies should consider the positive effects of MTEs [15,44]. Thus, this research verified the above propositions in the context of international tourism, and presented the first attempt to integrate MTEs, fun, and recommendation and revisit intentions into a causal model and investigate it empirically. It has therefore provided a new perspective and contribution to the understanding of the relationship between tourism experiences and behavioral intentions as a foundation for future research.

Fourthly, the works of Coudounaris and Sthapit [15] and Sharma and Nayak [26], which found that MTEs have considerable influences on tourists' behavioral intentions were confirmed. The antecedents of behavioral intention in the tourism field may be different from those in the general marketing field, as tourists pay more attention to experience quality. Even if tourists are satisfied with the environment and service of the destination, they will generally not revisit the destination. Only when a destination provides tourists with an unforgettable or memorable tourism experience will the tourists' willingness to recommend and revisit the destination be stronger. The findings of this research increase the knowledge of the positive effects of MTEs and provide a research framework for further research.

Fifthly, this study contributes to an improved understanding of the meaningful effects of MTEs, positive emotions such as fun, and behavioral intentions in the international tourism field. In this way, the existing knowledge about experiential marketing, consumer behavior, the importance of MTEs in tourism, and the important role of emotions in experiential consumption has been enhanced.

Finally, this study empirically tested the boundary conditions between positive emotions and behavioral intentions, and further examined the moderating role of perceived risk between the "fun" emotion and behavioral intention. This research represents the first exploration of the moderating effects of perceived risk between the "fun" emotion and behavioral intention, and provides new perspectives and directions for future related research.

In conclusion, this study empirically supported the proposed causal model of MTEs, fun, and recommendation and revisit intentions, and also confirmed the application of the S-O-R model in the international tourism field. In addition, the moderating effects of perceived risk between the "fun" emotion and behavioral intentions were examined. The findings are very beneficial to the understanding of the boundary conditions between the "fun" emotion and behavioral intentions of tourists, as well as to the understanding of the important role of MTEs, the "fun" emotion, and perceived risk in international tourist destination competition.

\subsection{Managerial Implications}

The first managerial implication of this study is the guiding of tourist destination marketers to focus on the important roles of MTEs and positive emotion, rather than only focusing on the product. Some tourist destinations are only focused on improving products, facilities, etc., and still insist on product-oriented marketing. They fail to stand in the shoes of tourists to consider their real needs when designing and providing experiences; they merely sell products or services. It is difficult for these destinations to gain overwhelming advantages and sustainable competitiveness in today's fiercely competitive international tourism market. 
The second managerial contribution of this paper is helping destination marketers and managers identify important psychological factors that influence tourists' MTEs. In this way, tourist destination marketers can design and provide unforgettable or memorable tourism experiences, such as designing a fun, novel experience, a meaningful experience, or a high-quality social interaction experience. Providing tourists with MTEs can stimulate their positive emotions such as fun, which in turn affect their recommendation and revisit intentions, and ultimately help to enhance the core competitiveness and sustainable growth of tourist destinations.

The third managerial contribution is helping destination marketers and managers effectively allocate resources while designing tourist projects by suggesting that they concentrate resources on components that can create MTEs. That is to say, tourism destination managers should consider the formation of MTEs when they allocate resources, and should strive for tourists to receive MTEs at the destination. Consequently, this would generate a stronger willingness for tourists to revisit, which would enhance the core competitiveness of the destination.

The fourth managerial contribution of this research is helping tourist destination managers to conduct better emotional management of tourists, and to develop and design experience projects that can stimulate tourists' positive emotions. Specifically, when destination marketers develop tourism projects, they should consider the tourists' emotions from tourists' perspectives, and strive to make them feel happy. This study found that the positive emotions generated by tourists through experiences will further positively induce their behaviors, which will have an important impact on the revenue and sustainable development of tourist destinations.

The final managerial contribution of this research is the recommendation that tourist destination marketers and managers should attempt to create a safe environment for tourists and publicize the comparative advantages of the destinations to reduce tourists' perceived risk. The lower the risk perceived by tourists, the greater the impact that the positive emotions received from the tourism experience will have on their recommendation and revisit intentions. Therefore, tourist destination managers, governments, and tourists should pay special attention to perceived risks. First, destination marketers and managers must strengthen safety management, strengthen security prevention and the inspection of tourism-related industries such as catering, accommodation, transportation, amusement, shopping, etc., and promote the standardization and institutionalization of safety management. They should also publicize safety inspection information via social media and other channels to shape a safe and attractive image of the destination, and highlight its comparative advantages. Additionally, they should summarize and publicize their comparative advantages and characteristics over competing destinations, increase tourists' understanding of the destination, and reduce the level of risk perception of tourists to increase tourists' revisit rate and recommendation intention and ultimately enhance the destination's market competitiveness. It is also necessary to train employees with international hospitality capabilities that are familiar with the language and living habits of foreign tourists to reduce the risk perception of tourists. Secondly, it is necessary for the government to severely crack down on illegal operations that disrupt the order of the tourism market, and to build a civilized and orderly tourism market environment for tourism consumption. The government should also strengthen social security management and severely crack down on illegal and criminal acts against tourists to create a peaceful and harmonious tourism environment. Finally, tourists should collect relevant information prior to travel, acquire a preliminary understanding of the tourist country and related scenic spots, and prepare for risk prediction and prevention to minimize the negative impact of perceived risk during the trip.

In summary, this study has important practical insights for how tourist destination marketing and management personnel can provide tourists with MTEs, and how tourists' loyalty behaviors can be enhanced. Tourist destination managers should train their employees, provide hedonic and novel experiences, create meaningful experience activities, design more activities that allow tourists to contact with others freely, pay special attention to tourists' emotions, and manage tourists' behaviors. In addition, destination managers should minimize the perceived risk of tourists to maximize tourists' 
revisit rate and recommendation intention, which will allow them to develop more effective marketing strategies to increase the destination's market share and international competitiveness.

\subsection{Limitations and Future Research}

Although this study has made important theoretical and managerial contributions, there remain some limitations. First, although the sample covered six representative cities in different geographical locations in China, and although the selected sample size met the statistical analysis requirements, the sample size was small in terms of the number of Chinese outbound tourists. Therefore, the sample cannot fully represent the entire Chinese outbound tourism market. Future research should adopt a larger sample size and include more cities, especially second- and third-tier cities with huge economic growth potential, to enhance the universality and generality of the research.

Second, the current research only used Chinese outbound tourists as the sample set. The behavioral characteristics of Chinese outbound tourists may be different from those of other international countries due to different cultural, political, economic, and historical factors, among others. Hence, cross-cultural research should be conducted in the future to identify whether there is a significant difference between the international and Chinese outbound tourism markets.

Third, only included psychological factors that affect MTEs were included in the model, and other factors, such as local culture and aesthetics, were not considered. Future research can incorporate other fundamental factors that influence MTEs into the S-O-R model and examine which factors have a more significant impact on tourists' emotions. Moreover, future research can extend the research framework to negative emotions such as regret, fear, and sadness to more clearly understand the behavioral motives of tourists.

Finally, when discussing the role of perceived risk, only the influence of age on the level of perceived risk was considered, and other factors that affect the level of risk perception were not taken into account; for example, the type of trip also has an important impact on the level of risk perception. Destinations naturally associated with a certain degree of risk, such as those known for mountaineering or skiing, have different effects on tourists' perceived risk level. In future studies, other factors that affect tourists' perceived risk, such as the type of trip, should be taken into account.

Author Contributions: Conceptualization, X.C., Z.-f.C. and G.-B.K.; data collection, X.C. and Z.-f.C.; software and analysis, X.C. and Z.-f.C.; writing-original draft, X.C.; review and editing, G.-B.K, and Z.-f.C.; project administration, G.-B.K. and Z.-f.C.; funding acquisition, G.-B.K. All authors have read and agreed to the published version of the manuscript.

Funding: This research was supported by the Daejeon University Research Grants 2016.

Conflicts of Interest: The authors declare no conflict of interest.

\section{References}

1. Zhu, D.; Wang, K.; Xu, H. The impact and implementation path of Chinese outbound tourism to construct China's soft power. World Reg. Stud. 2018, 27, 45-56.

2. UNWTO. Tourism towards 2030: Global Overview; UNWTO: Madrid, Spain, 2011.

3. Li, Z.J.; Sun, G.N. Spatial-temporal analysis of international influence for China's outbound tourism: Based on market share and growth contribution. J. Shaanxi Norm. Univ. 2019, 47, 59-66.

4. Lu, J.; Hung, K.; Wang, L.; Schuett, M.A.; Hu, L. Do perceptions of time affect outbound-travel motivations and intention? An investigation among Chinese seniors. Tour. Manag. 2016, 53, 1-12. [CrossRef]

5. UNWTO Workshop on Chinese Outbound Tourism Market. Available online: http://asiapacific.unwto.org/ event/unwto-workshop-chinese-outbound-tourism-market (accessed on 17 January 2018).

6. Liu, Y.; Huang, K.; Bao, J.; Chen, K. Listen to the voices from home: An analysis of Chinese tourists' sentiments regarding Australian destinations. Tour. Manag. 2019, 71, 337-347. [CrossRef]

7. Jiang, S.; Scott, N.; Ding, P.; Zou, T.T. Exploring Chinese outbound tourism motivation using means-end chains: A conceptual model. J. China Tour. Res. 2012, 8, 359-372. [CrossRef] 
8. Jiang, S.; Scott, N.; Tao, L.; Ding, P. Chinese tourists' motivation and their relationship to cultural values. Anatolia 2018, 30, 90-102. [CrossRef]

9. Xie, Y.; Li, M. Development of China's outbound tourism and the characteristics of its tourist flow. J. China Tour. Res. 2009, 5, 226-242. [CrossRef]

10. Yang, Y.; Jing, F.J.; Nguyen, B. China's outbound tourism: Investigating word-of-mouth and its effect on perceived value, satisfaction and loyalty. J. China Tour. Res. 2016, 12, 159-178. [CrossRef]

11. Meng, F.; Zhang, P.; Li, H.; So, K.K.F. Modeling precursors of impulsive tourist shopping behavior: Evidence from long-haul Chinese outbound tourists. Int. J. Tour. Res. 2019, 21, 344-358. [CrossRef]

12. Kim, H.; Chen, J.S. The memorable travel experience and its reminiscence functions. J. Travel Res. 2019, 58, 637-649. [CrossRef]

13. Myagmar, D.; Choi, C.J. Service experience and consumers' cognitive, affective and behavioral responses in a retail setting in Mongolia: The moderating effect of relationship duration. J. Int. Trade Comm. 2018, 14, 425-447. [CrossRef]

14. Ali, F.; Ryu, K.; Hussain, K. Influence of Experiences on memories, satisfaction and behavioral intentions: A study of creative tourism. J. Travel Tour. Mark. 2016, 33, 85-100. [CrossRef]

15. Coudounaris, D.N.; Sthapit, E. Antecedents of memorable tourism experience related to behavioral intentions. Psychol. Mark. 2017, 34, 1084-1093.

16. Kim, J. The antecedents of memorable tourism experiences: The development of a scale to measure the destination attributes associated with memorable experiences. Tour. Manag. 2014, 44, 34-45. [CrossRef]

17. Kim, J.-H.; Ritchie, J.; Tung, V. The effect of memorable experience on behavioral intentions in tourism: A structural equation modeling approach. Tour. Anal. 2010, 15, 637-648. [CrossRef]

18. Baker, D.A.; Crompton, J.L. Quality, satisfaction and behavioral intentions. Ann. Tour. Res. 2000, $27,785-804$. [CrossRef]

19. Lee, C.-K.; Yoon, Y.-S.; Lee, S.-K. Investigating the relationships among perceived value, satisfaction, and recommendations: The case of the Korean DMZ. Tour. Manag. 2007, 28, 204-214. [CrossRef]

20. Loureiro, S.M.C.; Gonzalez, F.J.M. The importance of quality, satisfaction, trust, and image in relation to rural tourist loyalty. J. Travel Tour. Mark. 2008, 25, 117-136. [CrossRef]

21. Ryu, K.; Han, H.; Kim, T.H. The relationships among overall quick-casual restaurant image, perceived value, customer satisfaction, and behavioral intentions. Int. J. Hosp. Manag. 2008, 27, 459-469. [CrossRef]

22. Choi, H.; Choi, H.C. Investigating tourists' fun-eliciting process toward tourism destination sites: An application of cognitive appraisal theory. J. Travel Res. 2019, 58, 732-744. [CrossRef]

23. Knobloch, U.; Robertson, K.; Aitken, R. Experience, emotion, and eudaimonia: A consideration of tourist experiences and well-being. J. Travel Res. 2017, 56, 651-662. [CrossRef]

24. Eid, R.; El-Kassrawy, Y.A.; Agag, G. Integrating destination attributes, political (in) stability, destination image, tourist satisfaction, and intention to recommend: A study of UAE. J. Hosp. Tour. Res. 2019, 43, 839-866. [CrossRef]

25. Huang, Y.-C.; Chen, C.-C.B.; Gao, M.J. Customer experience, well-being, and loyalty in the spa hotel context: Integrating the top-down \& bottom-up theories of well-being. J. Travel Tour. Mark. 2019, 36, 595-611.

26. Sharma, P.; Nayak, J.K. Understanding memorable tourism experiences as the determinants of tourists' behavior. Int. J. Tour. Res. 2019, 21, 504-518. [CrossRef]

27. Weiler, B.; Chen, H. Repositioning Australian cities as settings for memorable nature-based experiences aimed at Chinese tourists. Tour. Recreat. Res. 2016, 41, 246-258. [CrossRef]

28. Huang, S.; van der Veen, R. The moderation of gender and generation in the effects of perceived destination image on tourist attitude and visit intention: A study of potential Chinese visitors to Australia. J. Vacat. Mark. 2019, 25, 375-389. [CrossRef]

29. Gountas, J.; Gountas, S. Personality orientations, emotional states, Customer satisfaction, and intention to purchase. J. Bus. Res. 2007, 60, 72-75. [CrossRef]

30. Hultman, M.; Skarmeas, D.; Oghazi, P.; Beheshti, H.M. Achieving tourist loyalty through destination personality, satisfaction, and identification. J. Bus. Res. 2015, 68, 2227-2231. [CrossRef]

31. Prayag, G.; Hosany, S.; Muskat, B.; Del Chiappa, G. Understanding the relationships between tourists' emotional experiences, perceived overall image, satisfaction, and intention to recommend. J. Travel Res. 2017, 56, 41-54. [CrossRef] 
32. Mehrabian, A.; Russell, J.A. An Approach to Environmental Psychology; The MIT Press: Cambridge, MA, USA, 1974.

33. Lee, H.-J.; Yun, Z.-S. Consumers' perceptions of organic food attributes and cognitive and affective attitudes as determinants of their purchase intentions toward organic food. Food Qual. Prefer. 2015, 39, $259-267$. [CrossRef]

34. Cho, W.C.; Lee, K.Y.; Yang, S.B. What makes you feel attached to smartwatches? The stimulus-organism-response (S-O-R) perspectives. Inf. Technol. People 2019, 32, 319-343. [CrossRef]

35. Ettis, S.A. Examining the relationships between online store atmospheric color, flow experience and consumer behavior. J. Retail. Consum. Serv. 2007, 37, 43-55. [CrossRef]

36. Xiao, L.; Guo, F.; Yu, F.; Liu, S. The Effects of Online Shopping Context Cues on Consumers' Purchase Intention for Cross-Border E-Commerce Sustainability. Sustainability 2019, 11, 2777. [CrossRef]

37. Pine II, B.J.; Gilmore, J.H. Experience Economy: Work is Theatre and Every Business a Stage; Harvard Business School Press: Boston, MA, USA, 1999.

38. Sfandla, C.; Bjork, P. Tourism experience network: Co-creation of experiences in interactive processes. Int. J. Tour. Res. 2013, 15, 495-506. [CrossRef]

39. Walls, A.R.; Okumus, F.; Wang, Y.R.; Kwun, D.J.-W. An epistemological view of consumer experiences. Int. J. Hosp. Manag. 2011, 30, 10-21. [CrossRef]

40. Kim, J.-H.; Ritchie, J.R.B.; Mccormick, B. Development of a scale to measure memorable tourism experiences. J. Travel Res. 2012, 51, 12-25. [CrossRef]

41. Wei, C.; Zhao, W.; Zhang, C.; Huang, K. Psychological factors affecting memorable tourism experiences. Asia Pac. J. Tour. Res. 2019, 24, 619-632. [CrossRef]

42. Tung, V.W.S.; Ritchie, J.R.B. Exploring the essence of memorable tourism experiences. Ann. Tour. Res. 2011, 38, 1367-1386. [CrossRef]

43. Kim, J.-H.; Ritchie, J.R.B. Cross-cultural validation of a memorable tourism experience scale (MTES). J. Travel Res. 2014, 53, 323-335. [CrossRef]

44. Tsai, C.T.S. Memorable tourist experiences and place attachment when consuming local food. Int. J. Tour. Res. 2016, 18, 536-548. [CrossRef]

45. Holbrook, M.B.; Hirschman, E.C. The Experiential aspects of consumption: Consumer fantasies, feelings, and fun. J. Consum. Res. 1982, 9, 132-140. [CrossRef]

46. Davis, S.W.; Horváth, C.; Gretry, A.; Belei, N. Say what? How the interplay of tweet readability and brand hedonism affects consumer engagement. J. Bus. Res. 2019, 100, 150-164. [CrossRef]

47. Tasci, A.D.A.; Ko, Y.J. A fun-scale for understanding the hedonic value of a product: The destination context. J. Travel Tour. Mark. 2015, 33, 162-183. [CrossRef]

48. Holbrook, M.B. Consumption experience, customer value, and subjective personal introspection: An illustrative photographic essay. J. Bus. Res. 2006, 59, 714-725. [CrossRef]

49. Cheng, T.M.; Lu, C.C. Destination image, novelty, hedonics, perceived value, and revisiting behavioral intention for island tourism. Asia Pac. J. Tour. Res. 2013, 18, 766-783. [CrossRef]

50. Csikszentmihalyi, M.; Csikszentmihalyi, I. Beyond Boredom and Anxiety; Jossey-Bass: San Francisco, CA, USA, 1975.

51. Ma, J.; Campos, A.C.; Li, S.; Gardiner, S.; Scott, N. Attention, emotion and hedonic service experiences. Worldw. Hosp. Tour. Themes 2016, 8, 53-60. [CrossRef]

52. Litvin, S.W.; Goldsmith, R.E.; Pan, B. Electronic word-of-mouth in hospitality and tourism management. Tour. Manag. 2008, 29, 458-468. [CrossRef]

53. Chen, C.-F.; Tsai, D. How destination image and evaluative factors affect behavioral intentions? Tour. Manag. 2007, 28, 1115-1122. [CrossRef]

54. Wirtz, J.; Chew, P. The Effects of incentives deal proneness, satisfaction and tie strength on word-of-mouth behavior. Int. J. Serv. Ind. Manag. 2002, 13, 141-162. [CrossRef]

55. Hutchinson, J.; Lai, F.; Wang, Y. Understanding the relationships of quality, value, equity, satisfaction, and behavioral intentions among golf travelers. Tour. Manag. 2009, 30, 298-308. [CrossRef] 
56. Muskat, B.; Hörtnagl, T.; Prayag, G.; Wagner, S. Perceived quality, authenticity, and price in tourists' dining experiences: Testing competing models of satisfaction and behavioral intentions. J. Vacat. Mark. 2019, 25, 480-498. [CrossRef]

57. Chang, Y.-C.; Yeh, T.-M.; Pai, F.-Y.; Huang, T.-P. Sport activity for health!! The effects of karate participants' involvement, perceived value, and leisure benefits on recommendation intention. Int. J. Environ. Res. Public Health 2018, 15, 953. [CrossRef] [PubMed]

58. Day, G.S. Attitude change, media and word-of-mouth. J. Advert. Res. 1971, 11, 31-40.

59. Gyte, D.M.; Phelps, A. Patterns of destination repeat business: British tourists in Mallorca, Spain. J. Travel Res. 1989, 28, 24-28. [CrossRef]

60. Han, H.; Back, K.-J.; Barrett, B. Influencing factors on restaurant customers' revisit intention: The roles of emotions and switching barriers. Int. J. Hosp. Manag. 2009, 28, 563-572. [CrossRef]

61. Han, H.; Kim, Y. An investigation of green hotel customers' decision formation: Developing an extended model of the theory of planned behavior. Int. J. Hosp. Manag. 2010, 29, 659-668. [CrossRef]

62. Li, F.; Wen, J.; Ying, T. The influence of crisis on tourists' perceived destination image and revisit intention: An exploratory study of Chinese tourists to North Korea. J. Destin. Mark. Manag. 2018, 9, 104-111. [CrossRef]

63. Gursoy, D.; Gavcar, E. International leisure tourists' involvement profile. Ann. Tour. Res. 2003, 30, 906-926. [CrossRef]

64. Park, K.; Reisinger, Y. Differences in the perceived influence of natural disasters and travel risk on international travel. Tour. Geogr. 2010, 12, 1-24. [CrossRef]

65. Schroeder, A.; Pennington-Gray, L.; Kaplanidou, K.; Zhan, F. Destination risk perceptions among U.S. residents for London as the host city of the 2012 Summer Olympic Games. Tour. Manag. 2013, 38, 107-119. [CrossRef]

66. Reisinger, Y.; Mavondo, F. Travel Anxiety and intentions to travel internationally: Implications of travel risk perception. J. Travel Res. 2005, 43, 212-225. [CrossRef]

67. Hasan, M.K.; Ismail, A.R.; Islam, M.F. Tourist risk perceptions and revisit intention: A critical review of literature. Cogent Bus. Manag. 2017, 4, 1-21. [CrossRef]

68. Sharifpour, M.; Walters, G.; Ritchie, B.W. Risk perception, prior knowledge, and willingness to travel investigating the australian tourist market's risk perceptions towards the middle east. J. Vacat. Mark. 2014, 20, 111-123. [CrossRef]

69. Ritchie, B.W.; Chien, P.M.; Sharifpour, M. Segmentation by travel related risks: An integrated approach. J. Travel Tour. Mark. 2017, 34, 274-289. [CrossRef]

70. Sun, J. How risky are services? An empirical investigation on the antecedents and consequences of perceived risk for hotel service. Int. J. Hosp. Manag. 2014, 37, 171-179. [CrossRef]

71. Kim, L.H.; Qu, H.; Kim, D.J. A study of perceived risk and reduction of purchasing air tickets online. J. Travel Tour. Mark. 2009, 26, 203-224. [CrossRef]

72. Trauer, B.; Ryan, C. Destination image, romance and place experience: An application of intimacy theory in tourism. Tour. Manag. 2005, 26, 481-491. [CrossRef]

73. Dunham, L.; Freeman, R.E.; Liedtka, J. Enhancing stakeholder practice: A particularized exploration of community. Bus. Ethics. Q. 2006, 16, 23-42. [CrossRef]

74. Dunman, T.; Mattila, A. The role of affective factors on perceived cruise vacation value. Tour. Manag. 2005, 26, 311-323. [CrossRef]

75. Grappi, S.; Montanari, F. The role of social identification and hedonism in affecting tourist re-patronizing behaviours: The case of an Italian festival. Tour. Manag. 2011, 32, 1128-1140. [CrossRef]

76. Wearing, S.L.; McDonald, M.; Wearing, M. Consumer culture, the mobilisation of the narcissistic self and adolescent deviant leisure. Leis. Stud. 2013, 32, 367-381. [CrossRef]

77. Mason, M.C.; Paggiaro, A. Investigating the role of festival scape in culinary tourism: The case of food and wine events. Tour. Manag. 2012, 33, 1329-1336. [CrossRef]

78. Toyama, M.; Yamada, Y. The relationships among tourist novelty, familiarity, satisfaction, and destination loyalty: Beyond the novelty-familiarity continuum. Int. J. Mark. Stud. 2012, 4, 10-18. [CrossRef]

79. Lee, T.H.; Crompton, J. Measuring novelty seeking in tourism. Ann. Tour. Res. 1992, 19, 732-751. [CrossRef] 
80. Petrick, J.F. Development of a multi-dimensional scale for measuring the perceived value of a service. J. Leis. Res. 2002, 34, 119-134. [CrossRef]

81. Lee, Y.-I.; Chang, C.-H.; Chen, Y.-S. The Influence of novelty, flexibility, and synergy of package tours on tourist satisfaction: An analysis of structural equation modeling (SEM). Qual. Quant. 2011, 47, 1869-1882. [CrossRef]

82. Albaity, M.; Melhem, S.B. Novelty seeking, image, and loyalty: The mediating role of satisfaction and moderating role of length of stay: International tourists' perspective. Tour. Manag. Perspect. 2017, 23, 30-37. [CrossRef]

83. Noy, C. This trip really changed me: Backpackers' narratives of self-change. Ann. Tour. Res. 2004, 31, 78-102. [CrossRef]

84. Wilson, E.; Harris, C. Meaningful travel: Women, independent travel and the search for self and meaning. Tourism 2006, 54, 161-172.

85. Barnes, J.; Mattsson, J.; Sørensen, F. Remembered experiences and revisit intentions: A longitudinal study of safari park visitors. Tour. Manag. 2016, 57, 286-294. [CrossRef]

86. Liu, C. A study for tourist behavior and motivation. J. Psychol. Sci. 1999, 1, 67-69.

87. Lin, H.X.; Zhang, M.; Gursoy, D.; Fu, X.R. Impact of tourist-to-tourist interaction on tourism experience: The mediating role of cohesion and intimacy. Ann. Tour. Res. 2019, 76, 153-167. [CrossRef]

88. Lee, B.S.; Han, H.J. A Causal model among educational service quality, customer satisfaction and customer loyalty of students majoring in international trade. J. Korea Trade 2010, 14, $29-49$.

89. Claffey, E.; Brady, M. An empirical study of the impact of consumer emotional engagement and affective commitment in firm-hosted virtual communities. J. Mark. Manag. 2019, 35, 1047-1079. [CrossRef]

90. Huang, J.; Hsu, C.H.C. The Impact of customer-to-customer interaction on cruise experience and vacation satisfaction. J. Travel Res. 2010, 49, 79-92. [CrossRef]

91. Ali, F.; Kim, W.G.; Li, J.; Jeon, H.M. Make it delightful: Customers' experience, satisfaction and loyalty in Malaysian theme parks. J. Destin. Mark. Manag. 2018, 7, 1-11. [CrossRef]

92. Bilro, R.G.; Loureiro, S.M.C.; Guerreiro, J. Exploring online customer engagement with hospitality products and its relationship with involvement, emotional states, experience and brand advocacy. J. Hosp. Market. Manag. 2019, 28, 147-171. [CrossRef]

93. Ariffin, A.A.M.; Yahaya, M.F. The relationship between airport image, national identity and passengers delight: A case study of the Malaysian low cost carrier terminal (LCCT). J. Air Transp. Manag. 2013, 31, 33-36. [CrossRef]

94. Torres, E.N.; Kline, S. From satisfaction to delight: A model for the hotel industry. Int. J. Contemp. Hosp. Manag. 2006, 18, 290-301. [CrossRef]

95. Lin, J.; Liang, H. The influence of service environments on customer emotion and service outcomes. Manag. Ser. Qual. 2011, 21, 350-372. [CrossRef]

96. Ryu, K.; Han, H.; Jang, S.S. Relationships among hedonic and utilitarian values, satisfaction and behavioral intentions in the fast-casual restaurant industry. Int. J. Contemp. Hosp. Manag. 2010, 22, 416-432. [CrossRef]

97. Mattila, A.S.; Enz, C.A. The role of emotions in service encounters. J. Serv. Res. 2002, 4, 268-277. [CrossRef]

98. Jin, N.P.; Line, N.D.; Merkebu, J. The impact of brand prestige on trust, perceived risk, satisfaction, and loyalty in upscale restaurants. J. Hosp. Mark. Manag. 2015, 25, 523-546. [CrossRef]

99. Campbell, M.C.; Goodstein, R.C. The moderating effect of perceived risk on consumers' evaluations of product incongruity: Preference for the norm. J. Consum. Res. 2001, 28, 439-449. [CrossRef]

100. Wu, H.-C.; Li, M.-Y.; Li, T. A Study of experiential quality, experiential value, experiential satisfaction, theme park image, and revisit intention. J. Hosp. Tour. Res. 2014, 42, 26-73. [CrossRef]

101. Fuchs, G.; Reichel, A. Tourist destination risk perception: The case of Israel. J. Hosp. Leis. Mark. 2006, 14, 83-108. [CrossRef]

102. Jöreskong, K.G.; Sörbom, D. LISREL 8: Structural Equation Modeling with the SIMPLIS Command Language; Scientific Software International: Chicago, IL, USA, 1998.

103. McDonald, R.P.; Ho, M.H. Principles and practice in reporting structural equation analysis. Psychol. Methods 2002, 7, 64-82. [CrossRef]

104. Nunnally, J.C. Psychometric Theory, 2nd ed.; McGraw-Hill: New York, NY, USA, 1978. 
105. Fornell, C.; Larcker, D.F. Evaluating structural equation models with unobservable variables and measurement error. J. Mark. Res. 1981, 18, 39-50. [CrossRef]

106. Nunnally, J.C.; Bernstein, I.H. Psychometric Theory, 3rd ed.; McGraw-Hill: New York, NY, USA, 1994.

107. Hair, J.J.F.; Anderson, R.E.; Tatham, R.L.; Black, W.C. Multivariate Data Analysis, 5th ed.; Prentice Hall: Englewood Cliffs, NJ, USA, 1998.

108. Manthiou, A.; Kang, J.; Chiang, L. Investigating the effects of memorable experiences: An extended model of script theory. J. Travel Tour. Mark. 2016, 33, 362-379. [CrossRef]

(C) 2020 by the authors. Licensee MDPI, Basel, Switzerland. This article is an open access article distributed under the terms and conditions of the Creative Commons Attribution (CC BY) license (http://creativecommons.org/licenses/by/4.0/). 